\title{
Erosion, Geological History, and Indigenous Agriculture: A Tale of Two Valleys
}

\author{
Peter M. Vitousek, ${ }^{1 *}$ Oliver A. Chadwick, ${ }^{2}$ George Hilley, ${ }^{3}$ Patrick V. Kirch, ${ }^{4}$ \\ and Thegn N. Ladefoged ${ }^{5}$
}

\begin{abstract}
${ }^{1}$ Department of Biology, Stanford University, Stanford, California 94305, USA; ${ }^{2}$ Department of Geography, University of California, Santa Barbara, California 93106, USA; ${ }^{3}$ Department of Geological and Environmental Sciences, Stanford University, Stanford, California 94305, USA; ${ }^{4}$ Departments of Anthropology and Integrative Biology, University of California, Berkeley, California 94720, USA; ${ }^{5}$ Department of Anthropology, University of Auckland, Auckland, New Zealand
\end{abstract}

\begin{abstract}
Irrigated pondfields and rainfed field systems represented alternative pathways of agricultural intensification that were unevenly distributed across the Hawaiian Archipelago prior to European contact, with pondfields on wetter soils and older islands and rainfed systems on fertile, moderaterainfall upland sites on younger islands. The spatial separation of these systems is thought to have contributed to the dynamics of social and political organization in pre-contact Hawai'i. However, deep stream valleys on older Hawaiian Islands often retain the remains of rainfed dryland agriculture on their lower slopes. We evaluated why rainfed agriculture developed on valley slopes on older but not younger islands by comparing soils of Pololū Valley on the young island of Hawai'i with those of Hâlawa Valley on the older island of Moloka'i. Alluvial valley-bottom and colluvial slope soils of both valleys are enriched 4-5-fold in base saturation and in $\mathrm{P}$ that can be weathered, and greater than 10-fold in resin-extractable P and weatherable
\end{abstract}

Received 25 August 2009; accepted 7 June 2010; published online 7 July 2010

Author Contributions: PMV conceived the study, with input from OAC, PVK, and TNL, carried out the field sampling and soils data analysis, and wrote the first draft. GH carried out all geomorphological analyses and prepared illustrations, and all of the authors participated in revising the analyses and manuscript.

*Corresponding author; e-mail: vitousek@stanford.edu
Ca, compared to soils of their surrounding uplands. However, due to an interaction of volcanically driven subsidence of the young island of Hawai'i with post-glacial sea level rise, the side walls of Pololū Valley plunge directly into a flat valley floor, whereas the alluvial floor of Hālawa Valley is surrounded by a band of fertile colluvial soils where rainfed agricultural features were concentrated. Only $5 \%$ of Pololū Valley supports colluvial soils with slopes between $5^{\circ}$ and $12^{\circ}$ (suitable for rainfed agriculture), whereas $16 \%$ of Hālawa Valley does so. The potential for integrated pondfield/rainfed valley systems of the older Hawaiian Islands increased their advantage in productivity and sustainability over the predominantly rainfed systems of the younger islands.

Key words: erosion; geomorphology; Hawai'i; human-environment interaction; intensive agriculture; irrigation; soil fertility; subsidence; weathering. 
heterogeneity of the islands (Chadwick and others 2003; Vitousek 2004). The most widespread of these agricultural systems have been separated into two major classes-irrigated pondfields in which taro (Colocasia esculenta; in Hawaiian kalo) was the major crop, and rainfed uplands based on sweet potato (Ipomoea batatas; 'uala), dryland taro, and yams (Dioscorea sp; uhi) (Kirch 1994). Pondfields were established earlier in Hawaiian history; there is clear evidence for their existence by AD 1200 (Kirch 2002; McElroy 2007), and organized systems of pondfields were developed by AD 1400 (Allen 1992). In contrast, rainfed systems largely developed after $\mathrm{AD} 1400$, and show evidence for increased intensification after AD 1650 (Allen 2001; Coil and Kirch 2005; Kirch and others 2005; McCoy 2006; Ladefoged and Graves 2008).

These two classes of agro-ecosystems have profoundly different environmental requirements, and they were distributed unevenly across the archipelago at the time of European contact (Kirch 1994; Ladefoged and others 2009). Pondfields depend upon reliable sources of irrigation water and gentle slopes; they were developed extensively in well-watered alluvial and colluvial soils. Streams develop and the cumulative effects of erosion and sediment deposition increase with increasing rainfall and substrate age across the Hawaiian archipelago-and consequently pondfields largely were restricted to older northwestern islands, and to the oldest and wettest portions of the younger southeastern islands (Ladefoged and others 2009). In contrast, intensive rainfed systems require at least moderate rainfall $\left(>750 \mathrm{~mm} \mathrm{y}^{-1}\right)$ and relatively fertile soils (Vitousek and others 2004). Soil fertility on stable geomorphic surfaces decreases with increasing rainfall and substrate age (Chadwick and others 2003; Vitousek 2004); hence, rainfed systems developed primarily in leeward portions of the younger Hawaiian Islands, in environments very different from irrigated pondfields (Ladefoged and others 2009). The spatial and environmental separation between these two modes of intensive agricultural production could have played a substantial role in the dynamics and interactions of Hawaiian societies occupying the younger versus older islands in the archipelago (Kirch 1994; Graves and others, in press).

Despite the opposing nature of the conditions favoring irrigated and intensive rainfed systems, examples of what appear to be integrated systems including both the modes have been reported in valleys on older islands in the archipelago, with irrigated pondfields in valley bottoms and dryland agricultural features on lower slopes just above them (Kirch 1977; McElroy 2007). One mechanism that could underlie the development of such systems is the dual role that erosion can play in influencing soil fertility. Erosion removes soil and associated nutrients from surface soils, often limiting the productive capacity of agricultural ecosystems. However, erosion also exposes rock and littleweathered soil near the surface, making the effective age of the soil much younger than that of the geological substrate from which it was formed. This effect has the potential to enhance the fertility of both erosional and depositional areas. Studies that have used strontium isotopes as tracers of nutrient sources within native forest ecosystems in Hawai'i show that although the supply of nutrients derived from the weathering of soil minerals is depleted on stable geomorphic surfaces of the older islands (Kennedy and others 1998), the weathering source is rejuvenated and soil fertility is enhanced on lower slopes and in alluvial areas of those same landscapes (Vitousek and others 2003; Porder and others 2005). Similar enrichment of eroded slopes by rock-derived nutrients was observed on volcanic landscapes in Costa Rica (Porder and others 2006).

Palmer and others (2009) evaluated soil fertility, erosion, and their potential contribution to precontact agriculture on constructional geomorphic surfaces, slopes and valley bottoms on the wet windward side of Kohala volcano of the Island of Hawai'i-the oldest portion (150-600 ky) of the youngest island in the archipelago. Leeward Kohala supports a large rainfed agricultural system that is bounded by well-defined thresholds in climate and soil fertility (Vitousek and others 2004; Ladefoged and Graves 2008); the soil fertility threshold occurs where cumulative weathering and leaching have depleted soil minerals to the point that they no longer supply substantial quantities of nutrients or buffer atmospheric acidity (Chadwick and others 2003). This threshold shifts to progressively lower rainfall levels in progressively older substrates across the Hawaiian archipelago (Ladefoged and others 2009; Porder and Chadwick 2009).

Based on soil properties at the leeward soil fertility threshold, Palmer and others (2009) concluded that: (i) soils on constructional surfaces of windward Kohala are too infertile to support intensive rainfed agriculture, at least as it was practiced in leeward Kohala; (ii) erosion has a positive but small effect on soil fertility on slopes and alluvial areas in small $(<30-\mathrm{m}$ deep) stream valleys; and (iii) rock-derived nutrients dissolved in the streamwater used to irrigate pondfields sufficed to meet the nutrient demands of intensive pond- 
field agriculture in these smaller valleys. Palmer and others also analyzed soils in Pololū Valley, a large (>200-m deep) valley in windward Kohala; there, soil fertility on lower slopes and alluvium was enriched substantially relative to constructional surfaces or to smaller valleys. They suggested that most of the material transported by erosion in the small valleys was derived from low-fertility soils in the surrounding uplands, whereas most of the material in the large valley came from its steep and little-weathered walls.

Despite the fertility of lower-slope soils in the large Pololū Valley, its slopes are extremely steep all the way to the alluvium on the valley floor, and there is no evidence of intensive rainfed agriculture having been practiced on these slopes. Similar slope profiles occur in Waipi'o and Waimanu Valleys in windward Kohala; these are the largest valleys on the Island of Hawai'i, and their alluvial valley floors supported the most intensively irrigated areas on the island. In contrast, most large valleys on older islands in the archipelago have very different slope profiles, with an accumulation of gradually sloping colluvial material between their steep walls and relatively flat alluvial floors (MacDonald and others 1983). Why do large valleys on the older versus the younger islands in the Hawaiian Archipelago differ in structure? Are soils of the colluvial lower slopes on older islands fertile enough to support intensive rainfed agriculture? Could differences in valley structure have shaped pathways of agricultural development and intensification in pre-contact Hawai'i?

In this article, we compare topography, soil fertility, and associated agricultural potential in two large Hawaiian valleys, Pololū on the island of Hawai'i and Hālawa on the much older island of Moloka'i. We test the hypothesis that the geological processes of erosion and subsidence influenced pathways of agricultural development and intensification in these landscapes.

\section{MethoDS}

\section{Sites}

We focused on Pololū and Hālawa Valleys because they are comparable in size, relatively accessible, and because the archaeological remnants of Hawaiian agriculture have been surveyed in both. Pololū Valley $\left(20^{\circ} 12^{\prime} \mathrm{N}, 155^{\circ} 44^{\prime} \mathrm{W}\right)$ is the westernmost of seven large valleys on the windward northeastern flank of Kohala Volcano, the oldest subaerial portion of the Island of Hawai'i. Most of the lava within Pololū Valley is from the Pololū volcanic formation, older tholeiitic basalts that erupted from 400 to $600 \mathrm{ky}$ before present; younger flows of the later alkalic Hāwi formation (150-220 ky) cover much of the surrounding uplands and spill into the Valley. Wave-cut sea cliffs flank Pololū Valley on both sides, and the valley itself is from 200- to 400-m deep (Figure 1). Pololū has a long history of Hawaiian occupation (Handy and Handy 1972); it was colonized by AD 1200 (Field and Graves 2008), and evidence of both irrigated pondfields and rainfed agricultural systems (as well as later post-contact features) can be found on the broad, relatively flat floor of the valley (Tuggle and Tomonari-Tuggle 1980).

Hālawa Valley $\left(21^{\circ} 12^{\prime} 20^{\prime \prime} \mathrm{N}, 156^{\circ} 45^{\prime} \mathrm{W}\right)$ is the easternmost of four large valleys on the windward flank of east Moloka'i. The east Moloka'i volcano emerged approximately 1.8 million y (my) before present, and later alkalic eruptions covered most of its surface around 1.4 my ago. Like Pololū, Hālawa Valley is flanked by sea cliffs, and the main valley itself is approximately 300-m deep (Figure 1). Hālawa has a pre-contact cultural sequence dating from at least AD 1300 (Riley 1973; Kirch and Kelly 1975; Kirch 1990; Kirch and McCoy 2007). Its extensive irrigation systems are intact; a total of 693 pondfield terraces have been recorded in nine separate irrigation complexes (Riley 1975). The colluvial slopes above the irrigation systems on the valley floor exhibit dense archaeological landscapes of residential and rainfed agricultural features (Rosendahl 1975).

\section{Topography and Geological History}

We characterized the modern topography of Pololū and Hālawa Valleys using a 10-m digital elevation model (DEM) provided by the National Elevation Dataset (NED). Four 200-m-wide topographic swaths were selected to represent slope profiles in each valley, one near the valley outlet to the ocean, two in the center, and one just below the major waterfalls that bound the upper margin of the valley cores (Figure 1). Together, these transects sample more than $25 \%$ of each valley. The minimum, maximum, and mean elevations in the across-swath direction were computed for each point along the long dimension of the topographic swath. We compared mean elevations from each of the swaths by normalizing elevation and distance along the swath, and centering the swaths on the minimum swath elevation. 

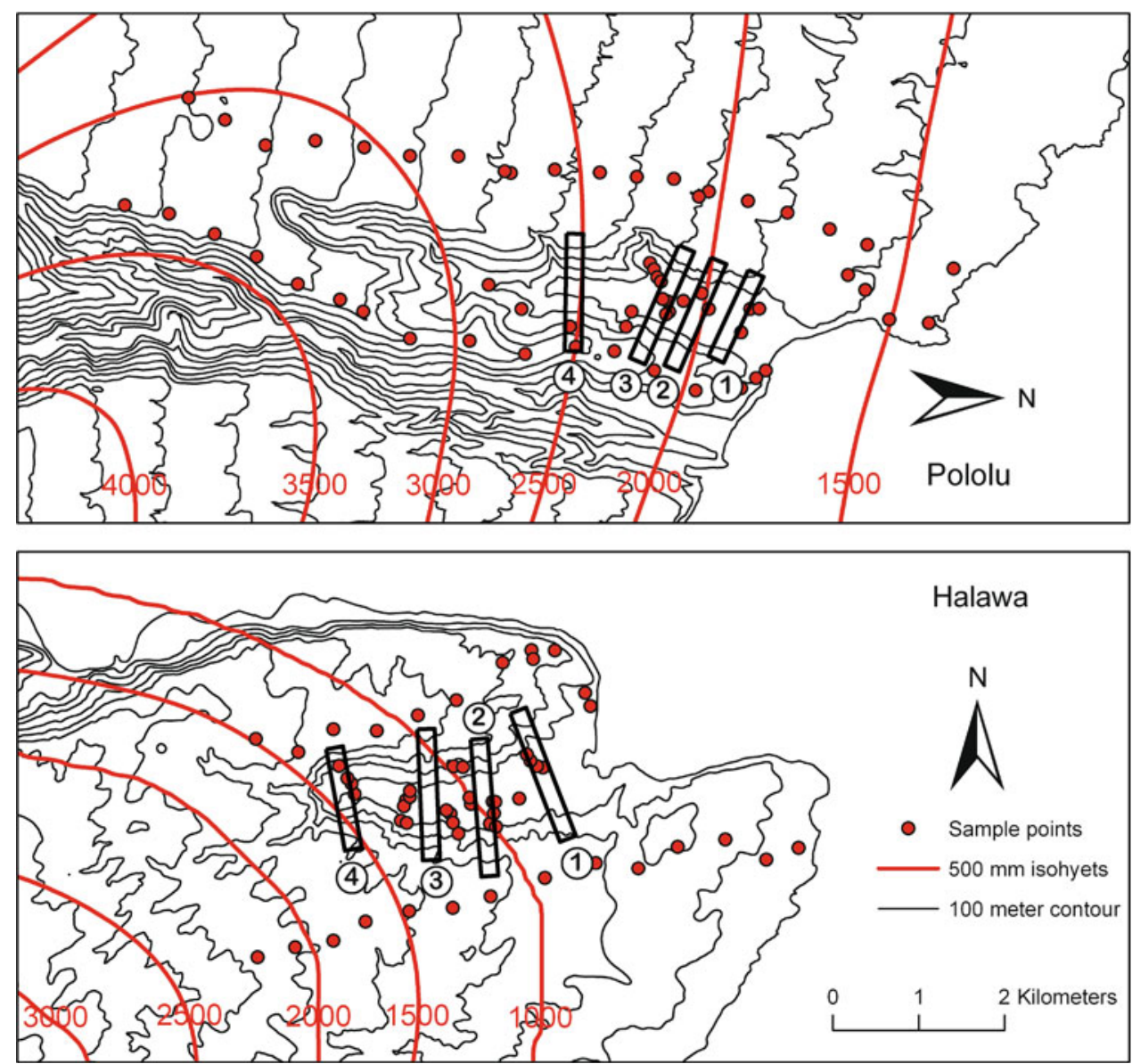

Figure 1. Pololū and Hālawa Valleys, on the Islands of Hawai'i and Moloka'i, respectively. The figures display elevation contours (thin lines), rainfall isohyets (thicker lines labelled with annual rainfall), and points where soil samples were collected (dots). Rectangles delineate swaths in which slope properties were determined (Figure 2).
Second, we calculated the distribution of slope angles across the full surface of each valley using a low-pass filter on the NED-DEM with a cut-off frequency of $0.05 \mathrm{~m}^{-1}$ (200-m wavenumber) to characterize the overall valley morphology by removing topography related to small individual gullies and ephemeral streams. From this filtered DEM, we extracted all filtered slope values within Pololū and Hālawa, summarizing these values as a cumulative distribution that denotes the fraction of the mapped valleys whose slopes are less than a given value.

\section{Soil Sampling}

We sampled alluvial and colluvial soils within each of the valleys, and along transects on upland soils on both sides of each valley; locations where soils were collected are shown in Figure 1. We collected integrated soil samples from 0 - to $30-\mathrm{cm}$ depth following protocols similar to those of Vitousek and others (2004), using a tiling shovel to expose a $30-\mathrm{cm}$ profile and collecting an integrated sample across this depth. This depth generally encompassed the soil that was churned by cultivator's digging sticks (Kirch and others 2005)—and in earlier studies (Vitousek and others 2004; Palmer and others 2009), the chemistry of these integrated 30$\mathrm{cm}$ samples correlated well with deeper (1-4 m) profiles collected across Kohala Volcano (Chadwick and others 2003; Porder and Chadwick 2009). Moreover, analyses of the $30-\mathrm{cm}$ samples provided consistent thresholds that defined the distribution of pre-contact rainfed agricultural systems (Kirch and others 2004, Vitousek and others 2004). Samples on the upland transects were collected systematically at approximately 500-m intervals, and sample positions were recorded via GPS. In Hālawa Valley, slope and alluvial samples were collected on transects reaching from alluvial soils near the main stream up to sloping colluvial soils, continuing upslope above any remnants of Hawaiian agriculture to the base of the cliffs that surround the valley. The basal slopes of Pololū are much steeper, and transect sampling was not feasible; instead, we collected alluvial and lower-slope soils widely across the valley and at the lowest portion of its steep slopes. Most of the alluvial and (in Hālawa) lower-slope samples were collected within long-abandoned (multiple decades) Hawaiian agricultural systems. 


\section{Soil Analyses}

Soils were air-dried, sieved $(2 \mathrm{~mm})$, and then divided into three homogenous subsamples, and all analyses were carried out as described in the supplemental material to Vitousek and others (2004). Briefly, one subsample was analyzed for total C and $\mathrm{N}$ using an elemental analyzer; a portion of this subsample also was extracted using the method of Kuo (1996) and analyzed for resin-extractable phosphorus using an Alpkem RFA/2 AutoAnalyzer. A second subsample was analyzed for cation exchange capacity (CEC) and exchangeable $\mathrm{Ca}, \mathrm{Mg}$, $\mathrm{Na}$, and $\mathrm{K}$ at the University of California, Santa Barbara, using the $\mathrm{NH}_{4} \mathrm{OAc}$ method at $\mathrm{pH} 7.0$ (Lavkulich 1981). The third subsample was shipped to ALS Chemex (Sparks, Nevada, USA) and analyzed for total concentrations of $\mathrm{Ca}, \mathrm{Mg}, \mathrm{Na}, \mathrm{K}, \mathrm{P}$, $\mathrm{Sr}$, and $\mathrm{Nb}$ using lithium borate fusion and $\mathrm{X}$-ray fluorescence spectrometry. Duplicate samples were incorporated in each procedure.

These measurements include some that reflect the forms of elements that are available to biota on relatively short time scales (resin P, exchangeable cations), and others that represent the total pools of elements and/or the cumulative effects of weathering. Available forms of elements can be dynamic; measurements reflect what was in the soil at the time of sampling, but those pools can change on annual time scales (or more frequently) and certainly are likely to have been influenced by human land use, both pre- and post-European contact. Total element pools are a more conservative measure; they include forms that are not immediately available to organisms, but they reflect the integrated outcome of additions and losses of elements playing out at time scales of decades or longer.

\section{Data Analyses}

With reference to an immobile index element, total element pools can be used to calculate the net loss or gain of elements from the soil. We used niobium $(\mathrm{Nb})$ as an index element because (with tantalum) it is the least mobile of the elements analyzed in Hawaiian soils (Kurtz and others 2000). The percentage of an element that remained in the soil sample relative to its basaltic parent material was calculated as:

$$
L_{i, j}=100 \times\left(C_{i, j} / C_{\mathrm{Nb}, j}\right) /\left(C_{i, \mathrm{pm}} / C_{N b, \mathrm{pm}}\right)
$$

where $L_{i, j}$ is the percentage of element $i$ remaining in soil sample $j ; C_{i, j}$ and $C_{\mathrm{Nb}, j}$ are the concentrations of element $i$ and of $\mathrm{Nb}$, respectively, in sample $j$; and $C_{i, \mathrm{pm}}$ and $C_{\mathrm{Nb}, \mathrm{pm}}$ are the element concentrations in basaltic parent material (Brimhall and others 1992). Values can exceed $100 \%$ where elements have been added to soils, either from outside the system or by vertical translocation within soil. This calculation assumes homogeneity in parent material, which is a more reasonable assumption on volcanic islands than it is in most places. Nevertheless, the $\mathrm{Ca} / \mathrm{Nb}$ ratio in parent material of different eruptive phases of Hawaiian volcanoes (younger tholeiitic versus older alkalic basalts) differs substantially; we assumed tholeiitic parent material was dominant at Pololū and alkalic parent material dominated Hālawa. The $\mathrm{P} / \mathrm{Nb}$ ratios in tholeiitic versus alkalic basalt are similar, so our assumptions about the provenance of soils are less important for $\mathrm{P}$ than for $\mathrm{Ca}$. These calculations of elements remaining from parent material provide a conservative estimate of the potential for soil minerals to supply more nutrients via weathering, and they should be relatively robust to changes in land use over time.

Statistical analyses were performed using Systat (Systat Software version 8; Systat, Chicago, Illinois, USA). All data were log-transformed to approximate the assumptions of analysis of variance (normality, homogeneity of variance). We employed one-way analyses of variance to test for significant variation in soil properties between sample locations (three factors: upland sites outside the valleys, and slope and alluvial sites within the valleys) for each valley and its surroundings. Where significant $F$ values from the overall ANOVA were obtained $(P<0.05)$, multiple pairwise comparisons were performed between groups using the conservative Bonferroni's correction for the $t$ test. We did not test the significance of differences between valleys; as illustrated below, the valleys differed in both rainfall and substrate age, and differences in soil properties between the valleys were influenced by both sources of variation.

\section{RESUlts}

\section{Topography and Geological History}

The topographic profiles of Pololū and Hālawa Valleys are summarized in Figure 2. As is apparent to observers in the field, the valley sidewalls in Pololū are generally steeper than those of Hālawa; although, the upstream portion of Hālawa Valley is steep relative to both its downstream portions and to Pololū Valley. Pololū and other large valleys on Kohala Volcano show an abrupt transition from steep, relatively planar valley sidewalls to a 


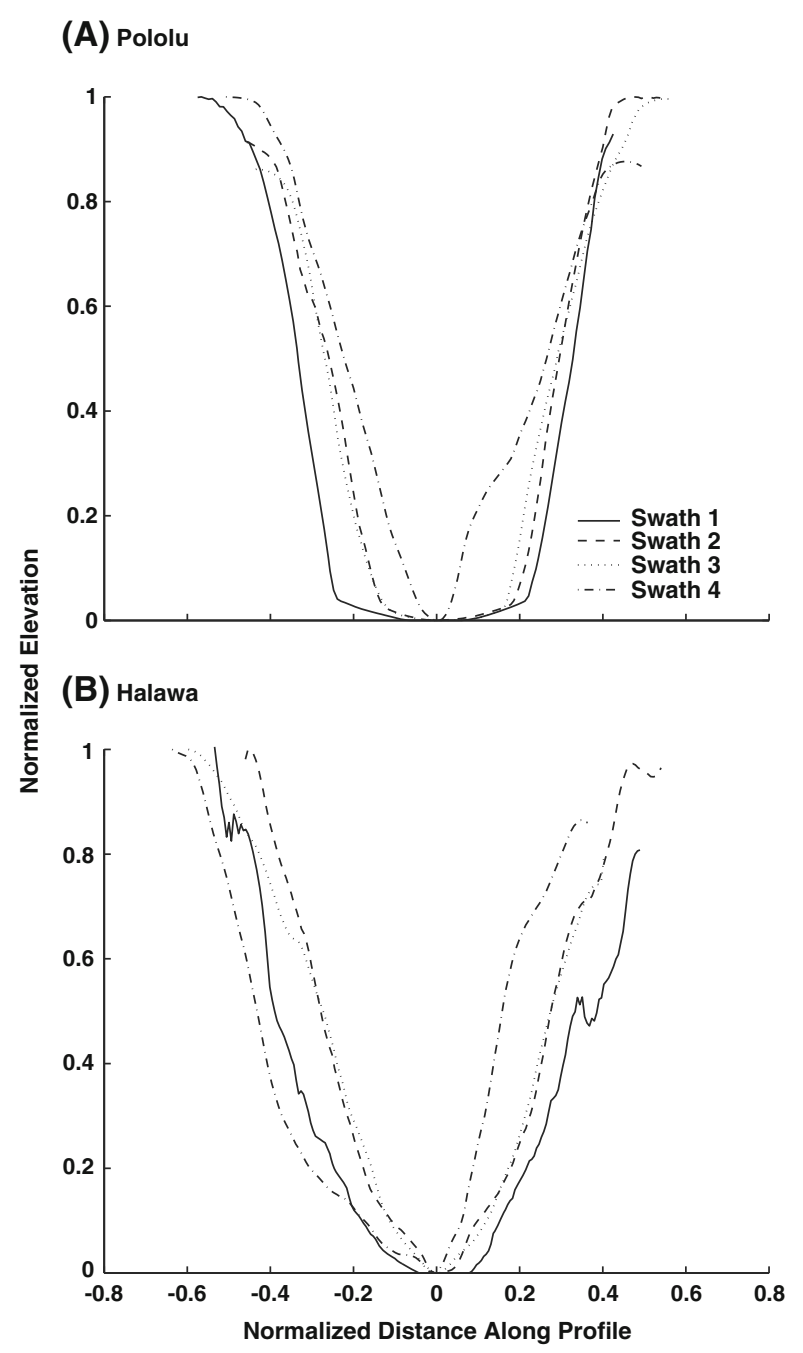

Figure 2. Normalized slope profiles for the rectangles displayed in Figure 1. Swath 1 is towards the mouth of each valley, swath 4 near the valley headwall. A Pololū and $\mathbf{B}$ Hālawa.

flat-bottomed valley floor that currently lies at or close to sea level (Macdonald and others 1983). In contrast, Hālawa and other large valleys on windward Moloka'i have valley sidewalls that transition from eroded cliffs to colluvial slopes to the alluvial valley floor, creating a continuous, concave-up landscape.

These different morphologies result from the differing subsidence histories experienced by the two islands over the last several hundred thousand years. Hawai'i Island is subsiding at a rate of approximately $2 \mathrm{~mm} \mathrm{y}^{-1}$ (Moore and Clague 1992), as a consequence of loading by the active volcanoes to the southeast of Kohala. In contrast, most eruptive activity on Moloka'i ceased over a million years ago, and the island currently is subsiding very little. Moreover, both the islands are now near the maximum of 120 -m sea-level fluctuations through glacial-interglacial cycles.

We can use this information on subsidence and sea level fluctuation to reconstruct the history of valley filling in Pololū since the last glacial maximum (Figure 3). Valley sidewall morphology was extrapolated to depth for each of the aggradational swaths in the front and in the center of Pololū Valley (Swaths 1-3; Figure 2), using the swath that was far enough from the coast to be buffered from aggradation associated with the marine transgression (Swath 4). Swaths 1-3 were backfilled using past sea-level reconstructions since about $20 \mathrm{ka}$ (Chappell and Shackleton 1986). Reconstructed valley bottom elevations along the northernmost swath in Pololū Valley correspond remarkably well with the 18-ka sea-level low stand, suggesting that the (overall) marine regression since around $120 \mathrm{ka}$ was instrumental in excavating material from the valley as the base level lowered. Since the last glacial maximum, ongoing rapid valley aggradation has filled Pololū with alluvial and colluvial sediments. In contrast, valley morphologies in Hālawa are consistent with continuous transport across a colluvial apron that is buffered from the high-frequency base-level variations associated with the recent history of sea-level changes.

In both Pololū and Hālawa, the maximum topographic slopes calculated from the low-passfiltered DEM tend to increase near the headwaters of these canyons, whereas downstream valley sidewalls are far less steep (especially in Hālawa, Figure 2). This observation is consistent with a scenario in which the headward-migrating canyon wall leaves progressively shallower valley sidewalls in its wake, as these initially steep slopes decrease and preserve an apron of colluvium across these portions of the landscape. This effect is far less pronounced in Pololū Valley, probably due to the youthfulness of this canyon system relative to Hālawa and to valley aggradation that buries the colluvial side-slopes.

\section{Soils}

Soils were collected across broad (and differing) rainfall gradients in and around the two valleys-particularly in the uplands (Figure 1), where sample locations received from about 1450 $3420 \mathrm{~mm} \mathrm{y}^{-1}$ of rain at Pololū and from around 875 to $2200 \mathrm{~mm} \mathrm{y}^{-1}$ at Hālawa (Giambelluca and others 1986). Consequently, mean values of soil properties (by valley and slope position) must be compared with caution. The distribution of soil properties with variation in rainfall provides a more 
Pololu

Halawa

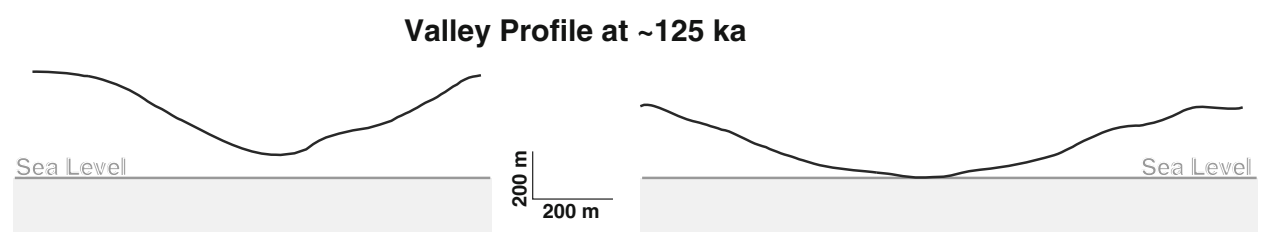

Valley Profile at $\sim 20 \mathrm{ka}$

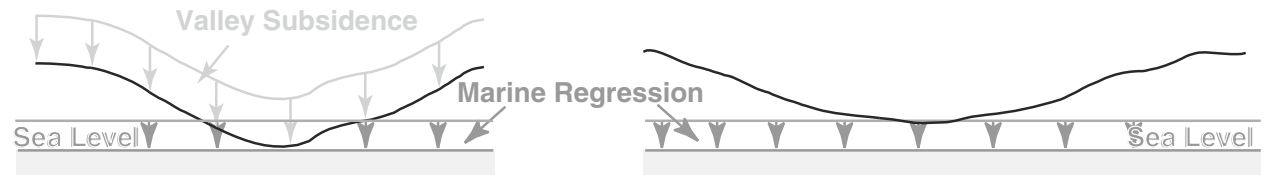

Current Valley Profile

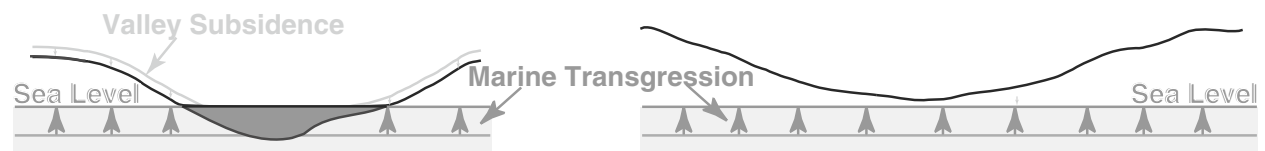

Figure 3. A model of the history of each valley for the past $125 \mathrm{ky}$. The dark line represents the valley profile; the area that now represents swath 1 in Pololū Valley was well above sea level during the last interglacial 125 ky ago. It subsided to the point where its base was at sea level at the last glacial maximum, approximately 20 ky ago. Subsequently, sea level rise (coupled with continuing subsidence) has taken the base of the valley below sea level, and the valley has been backfilled to its present flat-bottomed profile. In contrast, Hālawa Valley is not subsiding substantially, and its profile 125 ky ago is similar to its present profile.

direct measure of differences between valleys and among slope positions within valleys. These distributions are illustrated for base saturation and the percentage of $\mathrm{P}$ remaining (relative to parent material) in Figure 4; both of these measures are relatively stable indicators of soil fertility that correlate well with the boundaries of intensive rainfed agriculture in leeward Kohala (Vitousek and others 2004). Both base saturation and $P$ remaining decline with increasing rainfall in the uplands surrounding both valleys, consistent with numerous measurements of both $30 \mathrm{~cm}$ and deep soils along rainfall gradients in Hawai'i (Chadwick and others 2003; Vitousek and others 2004; Palmer and others 2009; Porder and Chadwick 2009). Where rainfall ranges overlap between the valleys, Hālawa soils are substantially lower in both base saturation and $\mathrm{P}$ remaining than are Pololū soils_-again consistent with numerous measurements that show declining soil fertility with increasing substrate age in Hawai'i (Crews and others 1995; Vitousek 2004; Chadwick and others 2009).

Alluvial and colluvial soils within both valleys had much higher base saturation and $P$ remaining than did upland soils with similar rainfall (Figure 4). Although the uplands surrounding both Pololū and Hālawa Valleys are nutrient-depleted and infertile, with most samples falling well below the thresholds that bounded intensive Hawaiian rainfed systems $(30 \%$ base saturation, $50-60 \% \mathrm{P}$ remaining) (Kirch and others 2004; Vitousek and others 2004), the slope and alluvial soils are well above these fertility thresholds (Figure 4). Not surprisingly, the remnants of intensive pre-contact agriculture were absent in the uplands and abundant in the alluvial areas of both valleys and the lower slopes of Hālawa.

Similar patterns of variation with rainfall and slope position were observed for most soil measurements, excluding only total $\mathrm{C}, \mathrm{N}$, and P. We summarize these comparisons in Tables 1 and 2, comparing slope and alluvial soils in each valley with upland soils that fall within a similar range of rainfall. Because Hālawa Valley is both older and has much lower rainfall than Pololū, we confine our statistical comparisons to slope positions within each valley and its surrounding uplands-although upland Hālawa soils are systematically less fertile than Pololū soils at comparable rainfall.

Analyses of variance for most soil properties (resin-extractable $\mathrm{P}, \mathrm{P}$ and $\mathrm{Ca}$ remaining from parent material, base saturation, exchangeable $\mathrm{Ca}, \mathrm{Mg}$, and $\mathrm{K})$ yielded significant $(P<0.001)$ differences with sample position in both valleys (Tables 1, 2); for these properties, in every case uplands were significantly lower in fertility/nutrient 


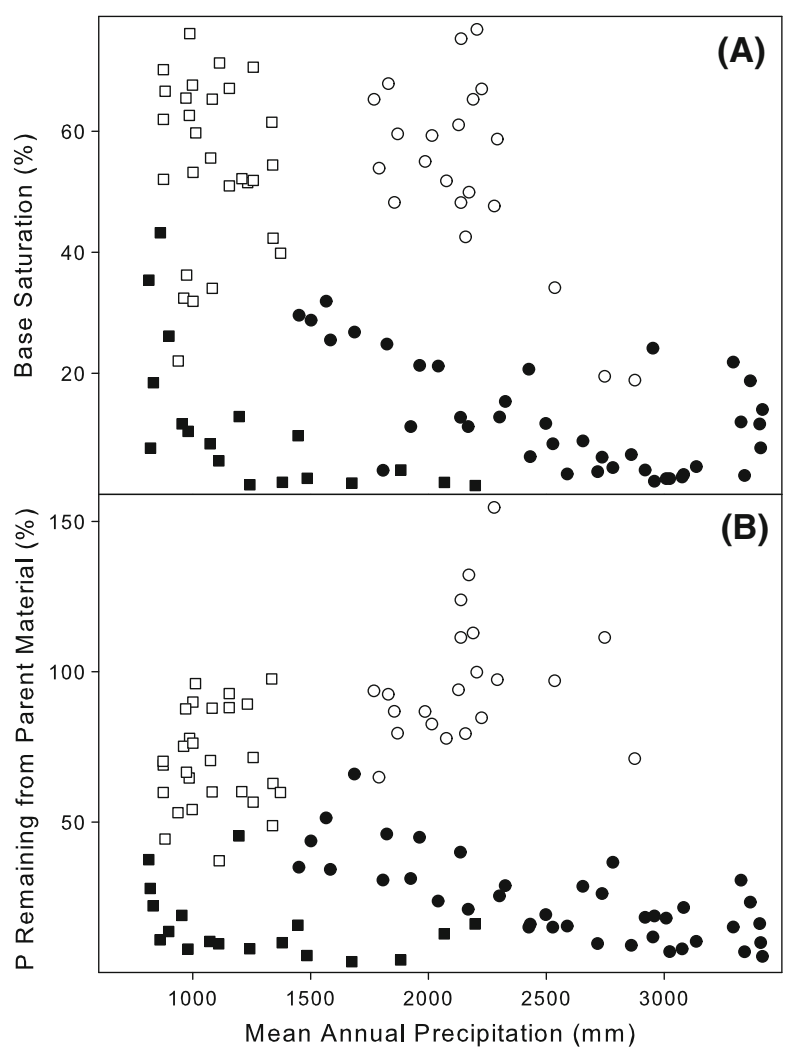

Figure 4. The distribution of base saturation $\mathbf{A}$ and the percentage of $\mathrm{P}$ remaining from parent material $\mathbf{B}$ versus mean annual rainfall within surface soils (to $30 \mathrm{~cm}$ ) in and around Pololū (circles) and Hālawa (squares) Valleys. Solid symbols represent upland soils; hollow symbols represent both slope and alluvial soils.

availability than were slope and alluvial positions, and slope did not differ significantly from alluvium. Total element pools ( $\mathrm{C}, \mathrm{N}$, and $\mathrm{P})$ displayed different patterns. There too analyses of variance yielded significant differences with sample position in both valleys $(P<0.05$ for total $\mathrm{N}$ at Hālawa, $P<0.01$ for total $\mathrm{P}$ at Pololū, $P<0.001$ for the rest). For $\mathrm{C}$ and $\mathrm{N}$, upland soils had significantly higher concentrations than slope and alluvial soils in both valleys; slope and alluvium did not differ significantly. For total P, upland and alluvial soils had significantly higher concentrations than slopes at Pololū, whereas upland soils had significantly lower total $\mathrm{P}$ than slope or alluvial soils (which did not differ significantly) at Hālawa.

We suggest that the greater total $\mathrm{C}$ and $\mathrm{N}$ pools of upland soils reflect their greater effective age, relative to slope and alluvial soils. Greater effective soil age in little-eroded uplands soils means a longer time for the accumulation of recalcitrant organic matter in older soils-and probably more importantly, it allows the accumulation of noncrystalline minerals that stabilize soil organic matter (Torn and others 1997). We further suggest that the patterns for total $\mathrm{P}$ are more complex because its pools reflect both weathering and loss (with cumulative effects that increase with increasing effective soil age) and retention by both organic matter and mineral adsorption, which are greater in the upland slope positions (Crews and others 1995; Miller and others 2001).c

\section{Discussion}

Overall, these results illustrate that erosion and deposition have a rejuvenating effect on the supply of rock-derived nutrients in these valley landscapes (Porder and others 2005, 2006)—one that suffices to make both lower slope and alluvial soils fertile enough to support intensive pre-contact agricultural systems in both valleys despite the infertility of the upland soils surrounding them. However,

Table 1. Base Saturation and Pools of Available Elements in Soils

\begin{tabular}{|c|c|c|c|c|c|c|}
\hline & \multicolumn{3}{|c|}{ Pololū-Hawai'i } & \multicolumn{3}{|c|}{ Hālawa-Moloka'i } \\
\hline & $\begin{array}{l}\text { Upland } \\
(N=18)\end{array}$ & $\begin{array}{l}\text { Slope } \\
(N=10)\end{array}$ & $\begin{array}{l}\text { Alluvial } \\
(N=11)\end{array}$ & $\begin{array}{l}\text { Upland } \\
(N=10)\end{array}$ & $\begin{array}{l}\text { Slope } \\
(N=18)\end{array}$ & $\begin{array}{l}\text { Alluvial } \\
(N=10)\end{array}$ \\
\hline Resin P $(\mu g / g)$ & $0.6(0.3)$ & $7.3(1.7)$ & $11(3.2)$ & $0.7(0.6)$ & $19(5.5)$ & $11(3.7)$ \\
\hline Base saturation (\%) & $11(4.3)$ & $53(1.9)$ & $55(3.0)$ & $12(3.0)$ & $61(1.9)$ & $43(5.1)$ \\
\hline \multicolumn{7}{|c|}{ Exchangeable cations (meq/100 g) } \\
\hline $\mathrm{Ca}$ & $3.0(0.5)$ & $15(2.5)$ & $13(1.5)$ & $2.2(0.8)$ & $16(0.9)$ & $11(2.9)$ \\
\hline $\mathrm{Mg}$ & $2.8(0.4)$ & $10(1.1)$ & $5.9(0.5)$ & $1.8(0.5)$ & $11(0.9)$ & $6.7(0.9)$ \\
\hline $\mathrm{K}$ & $0.4(0.05)$ & $1.1(0.2)$ & $1.1(0.1)$ & $0.2(0.1)$ & $1.4(0.1)$ & $1.1(0.3)$ \\
\hline
\end{tabular}


Table 2. Total Pools of $\mathrm{C}, \mathrm{N}$, and $\mathrm{P}$, and $\mathrm{P}$ and Ca Remaining from Parent Material

\begin{tabular}{|c|c|c|c|c|c|c|}
\hline & \multicolumn{3}{|c|}{ Pololū-Hawai'i } & \multicolumn{3}{|c|}{ Hālawa-Moloka'i } \\
\hline & $\begin{array}{l}\text { Upland } \\
(N=18)\end{array}$ & $\begin{array}{l}\text { Slope } \\
(N=10)\end{array}$ & $\begin{array}{l}\text { Alluvial } \\
(N=11)\end{array}$ & $\begin{array}{l}\text { Upland } \\
(N=10)\end{array}$ & $\begin{array}{l}\text { Slope } \\
(N=18)\end{array}$ & $\begin{array}{l}\text { Alluvial } \\
(N=10)\end{array}$ \\
\hline \multicolumn{7}{|c|}{ Total element concentrations ( $\%$ ) } \\
\hline Carbon & $7.5(0.6)$ & $4.6(0.5)$ & $4.8(0.7)$ & $6.0(0.7)$ & $3.4(0.2)$ & $3.3(0.2)$ \\
\hline Nitrogen & $0.66(0.05)$ & $0.43(0.039)$ & $0.45(0.052)$ & $0.40(0.047)$ & $0.30(0.022)$ & $0.28(0.021)$ \\
\hline Phosphorus & $0.27(0.022)$ & $0.17(0.042)$ & $0.22(0.008)$ & $0.14(0.017)$ & $0.20(0.020)$ & $0.27(0.012)$ \\
\hline \multicolumn{7}{|c|}{ Elements remaining from parent material $(\%)$} \\
\hline Phosphorus & $26(2.6)$ & $95(6)$ & $99(8)$ & $14(3.9)$ & $70(4.5)$ & $70(4.1)$ \\
\hline Calcium & $1.7(0.4)$ & $36(10)$ & $37(3)$ & $0.53(0.22)$ & $21(2.9)$ & $21(3.4)$ \\
\hline \multicolumn{7}{|c|}{$\begin{array}{l}\text { Concentrations of total pools of } C, N \text {, and } P \text { in soils of Pololu and Halawa Valleys, and the fraction of } P \text { and Ca that remains from the original parent material (calculated as } \\
\text { described in the text). The values for uplands are derived from transects on each side of the valleys, utilizing only sites with rainfall similar to the within-valley samples; slope } \\
\text { and alluvial samples come from the lower slopes of each valley and the alluvial material in the bottom of the valley, respectively. All values are means, with standard errors in } \\
\text { parentheses. ANOVA on log-transformed values yielded very highly significant differences }(P<0.001) \text { for each measure in each valley, except for total } P \text { in Pololu } P<0.01) \\
\text { and total } N \text { in Hälawa }(P<0.05) ; \text { Bonferroni-corrected } T \text { tests showed that upland soils differed significantly from slope and alluvial soils in every case except total } P \text { in } \\
\text { Pololü, for which slope soils differed significantly from upland and alluvial soils. This represented the only case in which slope and alluvial soils differed significantly. }\end{array}$} \\
\hline
\end{tabular}

differences in the structures of the valleys influenced their ability to support intensive agriculture prior to European contact. Hālawa Valley and other large valleys on older islands have well-developed colluvial aprons surrounding their alluvial floors. In contrast, Pololū Valley lacked the potential for lower-slope rainfed agriculture because the high subsidence rate of Hawai'i Island causes a sharp transition between slopes too steep to cultivate and the nearly flat valley floor (Figure 2)-a process that is accentuated by the rapid glacial-melt-driven sea level rise of the past approximately $20 \mathrm{ky}$ (Figure 3). Other major valleys on Kohala Volcano have similar structures-including the largest, Waipi'o Valley, which was a major center of precontact Hawaiian settlement.

Considering only the area bounded by the cliff tops on the valley sides and waterfalls at the head of the valleys, differences in subsidence rates and corresponding in-fill histories cause large differences in the distribution of slopes suitable for agriculture within Pololū and Hālawa (Figure 5). Assuming that slopes of less than $5^{\circ}$ could have been made suitable for intensive pondfield systems, $17 \%$ of the 423 ha surface of Pololū Valley could support pondfields (if enough water were available); only $6 \%$ of the 692 ha surface of Hālawa Valley had slopes less than $5^{\circ}$. Further, assuming that $12^{\circ}$ represents an upper threshold for intensive rainfed agriculture, $16 \%$ of Hālawa Valley has slopes between $5^{\circ}$ and $12^{\circ}$, as opposed to only $5 \%$ of Pololū Valley (Figure 5).

Available archaeological evidence for pre-contact agricultural systems in Pololū and Hālawa is consistent with our findings on valley topography and

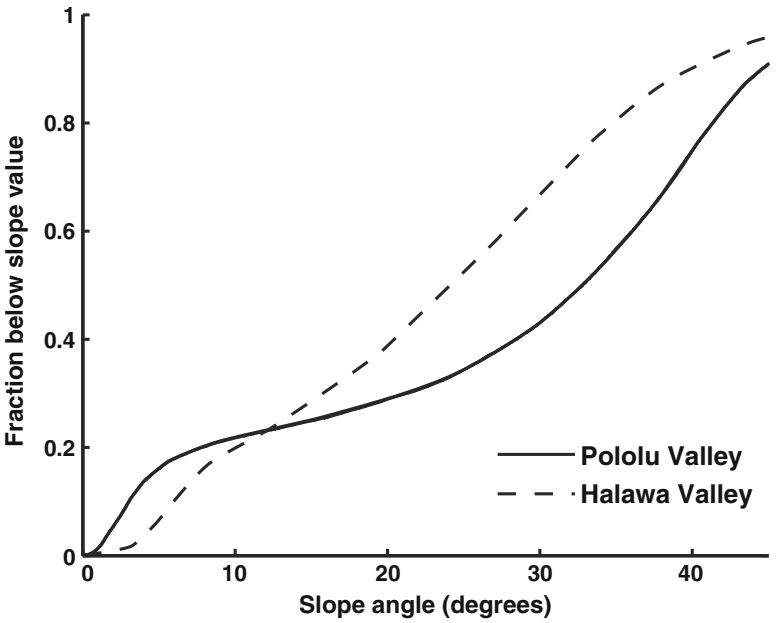

Figure 5. The cumulative distribution of slopes within Pololū and Hālawa Valleys, calculated as described in the text. Both valleys have equivalent fractions of their surface with slopes less than $12^{\circ}(22 \%)$, but a much larger fraction of Pololū Valley (17 vs. 6\%) has slopes less than $5^{\circ}$ that are suitable for the development of irrigated pondfield agriculture.

soil fertility. Tuggle and Tomonari-Tuggle (1980) found evidence for both irrigated and rainfed fields on the flat alluvial floor of Pololū. They attribute the fact that not all the Pololū alluvium was irrigated (despite greater yields from irrigated systems) to the valley's hydrologic conditions; the valley floor is so large relative to its watershed area that stream flow was inadequate to have watered the entire valley floor. In Hālawa Valley, the entire area of alluvium was converted to irrigated pondfields, which also extended onto the lower colluvial slopes (Riley 1975). More importantly, well-defined rainfed 
cultivation plots with stone-faced terraces and walls extend well up the colluvial slopes in Hālawa, encompassing an area greater than the total area of irrigated pondfields there. Rosendahl (1975; see also Kirch 1977) mapped the Kapana area of Hālawa Valley, providing a detailed example of intensive rainfed agricultural terraces, integrated with habitation sites and small temples. Significantly, mid-nineteenth century land records (the Mahele archives) from Hālawa demonstrate that most claimants included both irrigated $\left(l o^{\prime} i\right)$ as well as rainfed (kula) areas in their claims (Anderson 2001), showing that the two kinds of agriculture were integral parts of the overall production system at the household level.

The broader implications of this potential for intensive rainfed agriculture on colluvial slopes of the valleys on the older islands in the Hawaiian Archipelago are substantial. Analyses of the distribution of intensive agricultural systems and their consequences for the dynamics of Hawaiian society have considered irrigated and rainfed systems to have been spatially separated, due to the very different ecosystem and landscape properties that favor their development (Kirch 1994, in press; Vitousek and others 2004; Ladefoged and others 2009). Because these types of agricultural systems differ both in their ability to produce a surplus over agricultural labor and in their vulnerability to drought -with both comparisons favoring the irrigated pondfield systems-these contrasting systems could have contributed to the development of rather different societies, in areas or on islands dominated by one system or the other. The islands of Hawai'i and to a lesser extent Maui were based largely upon intensive rainfed systems, with only a few well-watered irrigated valleys. In contrast, the older islands in the archipelago have been thought to be based mostly upon irrigated pondfield systems. However, the evidence here suggests that the older islands likely maintained integrated pondfield/rainfed systems and that, as in Hālawa Valley, the peripheral rainfed systems could have covered a larger area than did irrigated pondfields. A similar pattern has been suggested in the leeward Mākaha Valley of $\mathrm{O}^{\prime} \mathrm{ahu}$, where archaeological survey confirmed the presence of extensive areas of dryland gardening on colluvial slopes, but where irrigation was confined to smaller areas in the valley interior (Hommon 1969, 1970; Yen and others 1972; Kirch 1977).

The potential for developing integrated pondfield/rainfed systems on colluvial slopes on the older islands strengthens the contrast between the agricultural production potential of Hawai'i Island versus the older islands. It has been suggested that pressures to maintain surplus production in rainfed, drought-prone agricultural areas could have driven the elites of Hawai'i Island towards marriage alliances (Cachola-Abad 2000) with elites of the older islands, and/or towards conquest of those islands (Kirch 1994) —and the development of integrated pondfield/rainfed systems on the older islands would only have increased their attractiveness as potential acquisitions. Moreover, integrated systems on the older islands could have boosted their potential agricultural yields, and the diversity of foods they could produce, to levels approaching the total productivity of the much larger island of Hawai'i (Ladefoged and others 2009). These dynamics should be incorporated into our understanding of the dynamics of Hawaiian society, and those of other indigenous societies in which similar dynamics could occur.

\section{ACKNOWLEDGEMENTS}

We thank Surety Kohala Corporation and Puu O Hoku Ranch for permission to sample on their lands; Lawrence Aki, Alton Arakaki, Mahealani Davis, Heraldo Farrington, Michael Gomes, and Christina Hoffman for assistance in the field; S. P. Hamburg for comments on an earlier draft; and Doug Turner for carrying out many of the laboratory analyses. Research was supported by a grant from the Andrew W. Mellon Foundation and by National Science Foundation grant BCS-0624346.

\section{OPEN ACCESS}

This article is distributed under the terms of the Creative Commons Attribution Noncommercial License which permits any noncommercial use, distribution, and reproduction in any medium, provided the original author(s) and source are credited.

\section{REFERENCES}

Allen J. 1992. Farming in Hawai'i from colonization to contact: Radiocarbon chronology and implications for cultural change. NZ J Archaeol 14:45-66.

Allen MS, Ed. 2001. Gardens of Lono: archaeological investigations at the Amy B. H. Greenwell Ethnobotanical Garden, Kealakekua, Kealakekua, Hawai'i. Honolulu: Bishop Museum. $167 \mathrm{p}$.

Anderson P. 2001. Houses of the Kama'aina: Historical Anthropology in a Rural Hawaiian Valley. Unpublished Ph.D. Dissertation, Dept. of Anthropology, University of California, Berkeley.

Brimhall GH, Chadwick OA, Lewis CJ, Compston W, Williams IS, Danti KJ, Dietrich WE, Power ME, Hendricks DM, Bratt J. 1992. Deformational mass transport and invasive processes in soil evolution. Science 255:695-702. 
Cachola-Abad CK. 2000. The evolution of Hawaiian sociopolitical complexity: an analysis of Hawaiian oral traditions. Ph.D thesis, University of Hawaii at Manoa.

Chadwick OA, Gavenda RT, Kelly EK, Ziegler K, Olson CG, Elliot WC, Hendricks DM. 2003. The impact of climate on the biogeochemical functioning of volcanic soils. Chem Geol 202:195-223.

Chadwick OA, Derry LA, Bern CR, Vitousek PM. 2009. Sources of strontium to soil minerals and ecosystems across the Hawaiian Islands. Chem Geol. doi:10.1016/jchemgeo.2009.01.009.

Chappell J, Shackleton NJ. 1986. Oxygen isotopes and sea level. Nature 324:137-40.

Coil J, Kirch PV. 2005. An Ipomoean landscape: Archaeology and the sweet potato in Kahikinui, Maui, Hawaiian Islands. In: Ballard C, Brown P, Bourke RM, Harwood T, Eds. The sweet potato in the Pacific: a reappraisal, Oceania Monograph 56 and Ethnology Monograph 19. Sydney and Pittsburgh. p 71-84.

Crews TE, Kitayama K, Fownes JH, Riley RH, Herbert DA, Mueller-Dombois D, Vitousek PM. 1995. Changes in soil phosphorus fractions and ecosystem dynamics across a long chronosquence in Hawai'i. Ecology 75:1407-24.

Field JS, Graves MW. 2008. A new chronology for Pololu Valley, Hawai'i Island: occupational history and agricultural development. Radiocarbon 50:205-22.

Giambelluca TW, Nullet MA, Schroeder TA. 1986. Rainfall Atlas of Hawaii. State of Hawaii Department of Land and Natural Resources Report R76, Honolulu.

Graves MW, Cachola-Abad CK, Ladefoged TN. Evolutionary ecology of Hawaiian political complexity: case studies from Maui and Hawai'i Island. In: Kirch PV, Ed. Roots of conflict: soils, agriculture, and sociopolitical complexity in ancient Hawai'i. Society for American Research, Santa Fe, NM (in press).

Handy ESC, Handy EG. 1972. Native planters in old Hawai'i: their life, lore, and environment. Honolulu: Bernice P. Bishop Museum Bulletin 233.641 p

Hommon RJ. 1969. An interim report on archaeological Zone 1. In: Green RC, Ed. Makaha Valley historical project: Interim report no. 1. Pacific Anthropological Records 4. Dept. Anthro., BPBM.

Hommon RJ. 1970. Subzone 1c of archaeological Zone 1 in the lower Makaha Valley. In: Green, Ed. Makaha Valley historical project: interim report no. 2. Pacific Anthropological Records 10. Dept. Anthro., BPBM. p 27-34.

Kennedy MJ, Chadwick OA, Vitousek PM, Derry LA, Hendricks DM. 1998. Changing sources of base cations during ecosystem development, Hawaiian islands. Geology 26:1015-18.

Kirch PV. 1977. Valley agricultural systems in prehistoric Hawaii: an archaeological consideration. Asian Perspect 20:246-80.

Kirch PV. 1990. The evolution of sociopolitical complexity in prehistoric Hawaii: an assessment of the archaeological evidence. J World Prehist 4:311-45.

Kirch PV. 1994. The wet and the dry: irrigation and agricultural intensification in Polynesia. Chicago: The University of Chicago Press.

Kirch PV. 2000. On the road of the winds: an archaeological history of the Pacific islands before European contact. Berkeley: University of California Press.

Kirch PV. 2002. From the 'Cliffs of Keolewa' to the 'Sea of Papaloa': an archaeological reconnaissance of the portions of the Kalaupapa National Historical Park, Moloka'i, Hawaiian
Islands. Oceanic Archaeology Laboratory Special Publication No. 2. Berkeley: University of California.

Kirch PV, Ed. Roots of conflict: soils, agriculture, and sociopolitical complexity in ancient Hawai'i. School of Advanced Research Press, Santa Fe (in press).

Kirch PV, Kelly M, Eds. 1975. Prehistory and ecology in a windward Hawaiian valley: Halawa Valley, Moloka'i. Pacific Anthropological Records 24. Honolulu: Bishop Museum, 205 p.

Kirch PV, McCoy M. 2007. Reconfiguring the Hawaiian cultural sequence: Results of re-dating the Halawa dune site (MO-Al3), Moloka'i Island. J Polyn Soc 116:385-406.

Kirch PV, Hartshorn AS, Chadwick OA, Vitousek PM, Sherrod DR, Coil J, Holm L, Sharp WD. 2004. Environment, agriculture, and settlement patterns in a marginal Polynesian landscape. Proc Natl Acad Sci USA 101:9936-41.

Kirch PV, Coil J, Hartshorn AS, Jeraj M, Vitousek PM, Chadwick OA. 2005. Intensive dryland farming on the leeward slopes of Haleakalā, Maui, Hawaiian Islands: archaeological, archaeobotanical, and geochemical perspectives. World Archaeol $37: 240-58$.

Kuo S. 1996. Phosphorus. In: Sparks DL, Ed. Methods of soil analysis, part 3. Chemical methods. Soil Science Society of America Book Series, vol 5. Soil Science Society of America, Madison. p 894-5.

Kurtz AC, Derry LA, Chadwick OA, Alfano MJ. 2000. Refractory element mobility in volcanic soils. Geology 28:683-6.

Ladefoged TN, Graves MW. 2008. Variable development of dryland agriculture in Hawai'i: a fine-grained chronology from the Kohala field system, Hawai'i Island. Curr Anthropol 49(5):771-802.

Ladefoged TN, Kirch PV, Gon SOIII, Chadwick OA, Hartshorn AS, Vitousek PM. 2009. Opportunities and constraints for intensive agriculture in the Hawaiian archipelago prior to European contact. J Archaeol Sci 36:2374-83.

Lavkulich LM. 1981. Methods manual: pedology laboratory. Vancouver, BC, CA: University of British Columbia, Department of Soil Science.

MacDonald GA, Abbot AT, Peterson FL. 1983. Volcanoes in the Sea: the geology of Hawaii. Honolulu, Hawaii: University of Hawaii Press.

McCoy MD. 2006. Landscape, social memory, and society: an ethnohistoric-archaeological study of three Hawaiian communities. Unpublished PhD Dissertation, University of California, Berkeley. 392 p.

McElroy W. 2007. The development of irrigated agriculture in Wailau Valley, Moloka'i Island, Hawai'i. Unpublished PhD Dissertation, University of Hawai'i, Manoa. 316 p.

Miller AJ, Schuur EAG, Chadwick OA. 2001. Redox control of phosphorus pools in montane forest soils in Hawaii. Geoderma 102:219-37.

Moore JG, Clague DA. 1992. Volcano growth and evolution of the Island of Hawai'i. Geol Soc Am Bull 104:1471-84.

Palmer MA, Graves MW, Ladefoged TN, Chadwick OA, Duarte TK, Porder S, Vitousek PM. 2009. Sources of nutrients to windward agricultural systems in pre-contact Hawai'i. Ecol Appl 19:1444-53.

Porder S, Chadwick OA. 2009. Climate and soil-age constraints on nutrient uplift and retention by plants. Ecology 90:623-36.

Porder S, Paytan A, Vitousek PM. 2005. Erosion and landscape development affect plant nutrient status in the Hawaiian Islands. Oecologia 142:440-9. 
Porder S, Clark DA, Vitousek PM. 2006. Persistence of rockderived nutrients in the wet tropical forests of La Selva, Costa Rica. Ecology 87:594-602.

Riley TJ. 1973. Wet and dry in a Hawaiian Valley: the archaeology of an agricultural system. Unpublished PhD Dissertation, University of Hawaii-Manoa.

Riley TJ. 1975. Survey and excavations of the aboriginal agricultural system. In: Kirch PV, Kelly M, Eds. Prehistory and ecology in a windward Hawaiian Valley: Halawa Valley, Molokai. Pacific Anthropological Records 24. Honolulu: Bishop Museum. p 79-116.

Rosendahl PH. 1975. Surface structural remains in Kapana. In: Kirch PV, Kelly M, Eds. Prehistory and ecology in a windward Hawaiian Valley: Halawa Valley, Molokai. Pacific Anthropological Records 24. Honolulu: Bishop Museum. p 71-7.

Torn MS, Trumbore SE, Chadwick OA, Vitousek PM, Hendricks DM. 1997. Mineral control of soil carbon storage and turnover. Nature 389:170-3.
Tuggle HD, Tomonari-Tuggle MJ. 1980. Prehistoric agriculture in Kohala, Hawai'i. J Field Archaeol 7:297-312.

Vitousek PM. 2004. Nutrient cycling and limitation: Hawai'i as a model system. Princeton: Princeton University Press.

Vitousek PM, Chadwick OA, Matson PA, Allison S, Derry LA, Kettley L, Luers A, Mecking E, Monastra V, Porder S. 2003. Erosion and the rejuvenation of weathering-derived nutrient supply in an old tropical landscape. Ecosystems 6:762-72.

Vitousek PM, Ladefoged TN, Kirch PV, Hartshorn AS, Graves MW, Hotchkiss SC, Tuljapurkar S, Chadwick OA. 2004. Soils, agriculture, and society in precontact Hawai'i. Science 304:1665-9.

Yen DE, Kirch PV, Riley T, Rosendahl P. 1972. Prehistoric agriculture in the upper valley of Makaha, Oahu. In: Ladd E, Yen DE, Eds. Makaha Valley Historical Project: Interim Report No. 3. Pacific Anthropological Records 18. Honolulu: Bernice P. Bishop Museum. p 59-94. 